\title{
Biomass burning aerosols in the southern hemispheric midlatitudes as observed with a multiwavelength polarization Raman lidar
}

\author{
Athena Augusta Floutsi ${ }^{1}$, Holger Baars ${ }^{1}$, Martin Radenz ${ }^{1}$, Moritz Haarig ${ }^{1}$, Zhenping Yin ${ }^{1,2,3}$, \\ Patric Seifert $^{1}$, Cristofer Jimenez ${ }^{1}$, Ulla Wandinger ${ }^{1}$, Ronny Engelmann ${ }^{1}$, Boris Barja ${ }^{4}$, \\ Felix Zamorano ${ }^{4}$, and Albert Ansmann ${ }^{1}$ \\ ${ }^{1}$ Leibniz Institute for Tropospheric Research, Leipzig, Germany \\ ${ }^{2}$ School of Electronic Information, Wuhan University, Wuhan, China \\ ${ }^{3}$ Key Laboratory of Geospace Environment and Geodesy, Ministry of Education, Wuhan, China \\ ${ }^{4}$ Atmospheric Research Laboratory, University of Magallanes, Punta Arenas, Chile
}

Correspondence: Athena Augusta Floutsi (floutsi@tropos.de)

\begin{abstract}
In this paper, we present long-term observations of the multiwavelength Raman lidar Polly ${ }^{X T}$ conducted in the framework of the DACAPO-PESO campaign. Regardless the relatively clean atmosphere in the southern mid-latitude oceans region, we observed regularly events of long-range transported smoke, originating either from regional sources in South America or from Australia. Two case studies will be discussed. Both cases were identified as smoke events and they occurred on 5

5 February 2019 and 11 March 2019. For the first case considered, the lofted smoke layer was located at an altitude between 1 and $4.2 \mathrm{~km}$, and apart from the predominance of smoke particles, particle linear depolarization values indicated the presence of dust particles in the layer. Mean lidar ratio values at 355 and $532 \mathrm{~nm}$ were $49 \pm 12$ and $24 \pm 18$ sr respectively, while the mean particle linear depolarization was $7.6 \pm 3.6 \%$ at $532 \mathrm{~nm}$. The advection of smoke and dust particles above Punta Arenas affected significantly the available $\mathrm{CCN}$ and INP in the lower troposphere, and triggered effectively ice crystal formation processes. Regarding the second case, the thin smoke layers were observed at altitudes between 5.5-7, 9 and $11 \mathrm{~km}$. The particle linear depolarization ratio at $532 \mathrm{~nm}$ increased rapidly with height, starting from $2 \%$ for the lowest two layers and increasing up to $9.5 \%$ for the highest layer, indicating the possible presence of non-spherical coated soot aggregates. INP activation was effectively facilitated. The long-term analysis of the one year of observations showed that tropospheric smoke advection over Punta Arenas occurred 16 times (lasting from 1 to 17 hours), regularly distributed over the period and with high potential to influence cloud formation in the otherwise pristine environment of the region.
\end{abstract}

\section{Introduction}

Punta Arenas $\left(53.2^{\circ} \mathrm{S}, 70.9^{\circ} \mathrm{W}\right)$ is located at the Strait of Magellan, at the southern tip of South America (location indicated with yellow star in Fig. 1). Constant westerly to north-westerly winds prevail through the whole year induced by the Antarctic low-pressure belt (Schneider et al., 2003). Since it is located in the most southerly continental area (with the exception of Antarctica), with New Zealand, Tasmania and Australia being the nearest $(>8.000 \mathrm{~km})$ landmasses towards the direction of the prevailing winds, clean pristine marine air masses dominate the aerosol conditions. The aforementioned geographical and 
climatic conditions make Punta Arenas an ideal test-bed for studies of aerosol, aerosol-cloud and radiation interactions under rather clean conditions with low anthropogenic impact (Kanitz et al., 2011, 2014; Foth et al., 2019).

In the southern mid-latitudes, there is a lack of long-term ground-based remote-sensing observations of aerosols and clouds, mainly due to the absence of substantial land masses below 40 degrees latitude. Immler and Schrems (2002) used the pristine location of Punta Arenas to contrast the properties of mid-latitude cirrus clouds from those observed in the aerosol-burden northern midlatitudes. First lidar-based studies of the vertical aerosol distribution over Punta Arenas have been performed in the frame of the Aerosol Lidar measurement at Punta Arenas in the frame of Chilean germAn cooperation (ALPACA) campaign (Kanitz et al., 2013; Baars et al., 2016; Foth et al., 2019). The portable Raman lidar Polly $X T$ (Althausen et al., 2009; Engelmann et al., 2016) was deployed at the Magallanes University in Punta Arenas and operated continuously for 4 months (4 Dec. 2009 - 4 Apr. 2010). During the ALPACA campaign, pristine marine conditions dominated the measurements, while lofted aerosol layers were observed only eight times. From these eight lofted layers examined, seven of them had an aerosol optical thickness less than 0.05. The origins of these layers were mainly bush fires in Australia and Patagonian dust (Foth et al., 2019).

As a follow-up of ALPACA, the Dynamics, Aerosol, Cloud and Precipitation Observations in the Pristine Environment of the Southern Ocean (DACAPO-PESO) campaign started in November 2018 as a collaboration between the Leibniz Institute for Tropospheric Research (TROPOS), the Leipzig Institute for Meteorology (LIM) and the University of Magallanes (UMAG) in Punta Arenas, Chile. DACAPO-PESO is focused on the investigation of cloud formation and aerosol-cloud interaction in environments of contrasting aerosol conditions and relies mainly on synergistic algorithms using state-of-the-art lidar and radar techniques (more information in Sec. 2). Within this publication, we present lidar observations of the vertical aerosol distribution above Punta Arenas during two interesting events that took place during the DACAPO-PESO campaign. These events demonstrate distinctively different lofted aerosol layers (in terms of physical and optical properties) in the clean and pristine environment of Punta Arenas. Since aerosol particles influence the evolution, lifetime, and microphysical properties of clouds by acting as cloud condensation nuclei (CCN) and ice nucleating particles (INP), CCN and INP concentrations were derived from the lidar signals for the corresponding cases.

This paper is organized as follows: Section 2 provides information on the experiment, our data sources, instrumentation and methodology. Section 3 presents our analysis for two different smoke events as observed over the site of Punta Arenas, focusing on the optical properties of the aerosol particles. Section 4 gives an overview of all the lofted layers that were observed, above our measurement site, during 2019. Section 5 discusses the main findings and highlights the most important conclusions of this study.

\section{Experiment and Instrumentation}

The DACAPO-PESO (https://dacapo.tropos.de/) campaign started in November 2018 and will continue until June 2020. This 19 month campaign is focused on aerosol, clouds, ice nucleation particles and aerosol-cloud dynamics relationships in the pristine environment of the southern-hemisphere midlatitudes. These complex topics need a synergistic approach in terms of 

was deployed on site $\left(53.2^{\circ} \mathrm{S}, 70.9^{\circ} \mathrm{W}, 9 \mathrm{~m}\right.$ a.s.1.). LACROS comprises a unique set of active and passive remote-sensing instruments which are to a large extent containerized (Fig. 1). More specifically, some key components are a $35 \mathrm{GHz}$ cloud radar, a Raman and depolarization lidar as part of PollyNET (Baars et al., 2016), a 2- $\mu \mathrm{m}$ scanning Doppler lidar, a 24-GHz micro rain radar, a microwave radiometer, a Sun photometer, a disdrometer and a radiation station with an all-sky camera. In addition, a 94-GHz cloud radar (provided by LIM) was also deployed until 1 October 2019. A Sun photometer was installed on the roof platform of the main building of UMAG, as part of the Aerosol Robotic Network (AERONET, Holben et al. (1998)). The LACROS observations are accompanied by regular observations of a multi-wavelength lidar of UMAG, which is operated at the site since 2016 in the frame of the South American Environmental Risk Management Network (SAVER-Net) and the Latin-American Lidar Network (LALINET) (Ristori et al., 2018).

\subsection{Lidar measurements}

In this paper, we will focus on atmospheric measurements which were conducted with the Raman lidar Polly ${ }^{X T}$ (Engelmann et al., 2016; Baars et al., 2016). Polly ${ }^{X T}$ utilizes a Nd:YAG laser that emits light at 3 different wavelengths, that are 355,532 and $1064 \mathrm{~nm}$. The receiver consists of 12 channels and enables measurements of elastically (355, 532, $1064 \mathrm{~nm})$ and Raman scattered light (387, $607 \mathrm{~nm}$ for aerosols and $407 \mathrm{~nm}$ for water vapour), depolarization state of the backscatter light (at 355 and $532 \mathrm{~nm}$ ). A near-range telescope allows the detection of $355 \mathrm{~nm}, 387 \mathrm{~nm}, 532 \mathrm{~nm}$, and $607 \mathrm{~nm}$ scatter light from about 60-80 $\mathrm{m}$ above ground. Vertical profiles can be obtained with an uppermost detection height of around $20 \mathrm{~km}$ a.g.l. (above ground level). Data from all channels are acquired with a vertical resolution of $7.5 \mathrm{~m}$ and a temporal resolution of $30 \mathrm{~s}$. The extinction and backscatter coefficients were determined as described by Ansmann and Müller (2005), while the depolarization ratio was determined according to standard procedures applied in the European lidar network EARLINET (D'Amico et al., 2015; Mattis et al., 2016). Quality assurance (e.g.Wandinger et al. (2016); Freudenthaler (2016); Belegante et al. (2018)) is a key aspect, even when Polly lidar systems are operated outside Europe. Regarding the signal analysis, the influence of noise to the lidar signals was reduced by means of a vertical gliding averaging filter. Window lengths varied for the two cases considered, such as not to lose any important structural information through the process of averaging. For the first case a window length of 562.5 $\mathrm{m}$ was applied for the backscatter coefficient, Ångström exponent and particle linear depolarization ratio, while a window length of $1492.5 \mathrm{~m}$ was applied for the much noisier lidar ratio. For the second case, a window length of $307.5 \mathrm{~m}$ was used for the backscatter coefficient and the particle linear depolarization ratio profiles, and a length of $1492.5 \mathrm{~m}$ was applied to the Ångström exponent.

The presented CCN and INP concentrations have been derived following the methodology proposed in Mamouri and Ansmann (2016). Firstly the dust and smoke contribution was separated using the particle linear depolarization ratio. A lidar ratio of $50 \mathrm{sr}$ for smoke and $55 \mathrm{sr}$ for dust was used to obtain the extinction coefficient per aerosol type. The smoke-related extinction coefficient is transferred to the number concentration $n_{50, c}$ of particles with dry radius larger than $50 \mathrm{~nm}$ (for CCN) and 
the surface area concentration $s_{c}$ (for INP) using the following equations:

$n_{50, c}=c_{60, c} \times \sigma_{c}^{\chi_{c}}$

with $c_{60, c}=25.3 \mathrm{~cm}^{-3}$ for $\sigma=1 \mathrm{Mm}^{-1}, \chi_{c}=0.94$ and $c_{s, c}=2.80 \times 10^{-12} \mathrm{Mm} \times \mathrm{m}^{2} \times \mathrm{cm}^{-3}$ at $532 \mathrm{~nm}$ based on long-term Aeronet observations over Leipzig (Mamouri and Ansmann, 2016). To reduce the uncertainties, a specific parameterization for smoke is under development. All soot particles with a dry diameter larger than $50 \mathrm{~nm}$ are assumed to activate as CCN at a supersaturation of $0.2 \%$. More specifically, the INP parameterizations and input parameters for soot and dust are from Ullrich et al. (2017), in accordance with the temperature regime of each case studied. Measurement quicklooks for the whole campaign period are available at http://polly.tropos.de in near real-time.

\subsection{Auxiliary data}

The Sun photometer located at UMAG $\left(53.1^{\circ} \mathrm{S}, 70.9^{\circ} \mathrm{W}, 25 \mathrm{~m}\right.$ a.s.1., site name: Punta_Arenas_UMAG), measures the columnintegrated extinction coefficient at 8 channels from 340 to $1640 \mathrm{~nm}$. Level 1.5 AOD data are used with a corresponding uncertainty of 0.01-0.02 (Holben et al., 2001).

For the analysis of the air mass transport the HYSPLIT model was used (Stein et al., 2015). HYSPLIT model calculates backward and forward trajectories of air masses for simulations of dispersion and deposition at a given location. In order to identify the aerosol sources and to create some statistical basis of the aerosol conditions during DACAPO-PESO, we used ensemble backward trajectories combined with a land cover classification for a temporally and vertically resolved air mass source attribution TRACE (Radenz and Seifert, 2019). A simplified version of the MODIS land cover (Friedl et al., 2002) is used. As a first step, a 27-member ensemble of 10 day backward trajectories is calculated using HYSPLIT. Meteorological input data for HYSPLIT were downloaded from the Global Data and Assimilation Service (GDAS1; https://www.ready.noaa.gov/gdas1.php) provided by the Air Resources Laboratory (ARL) of the US National Weather Service's National Centers for Environmental Prediction (NCEP). Each ensemble is generated using a small spatial offset in the trajectory endpoint. Whenever a trajectory is located below the planetary boundary layer (PBL) height provided by the GDAS1 data ("reception height"), the land cover is categorized using custom defined polygons according to land mass boundaries. It is therefore assumed that an air parcel is influenced by the surface type if the corresponding trajectory is below the PBL height. The residence time for each category is then the total time an air parcel fulfilled this criterion by land cover category. This calculation is repeated in steps of $3 \mathrm{~h}$ in time and $500 \mathrm{~m}$ in height in order to provide a continuous estimate on the source of the air mass and a first indication on the potential aerosol load. 


\section{Case Studies}

In this section, two of the most distinctive cases with lofted aerosol layers that were identified above Punta Arenas are presented in detail. The first one presents a 3-km thick lofted aerosol layer, located in the lowest troposphere between 1 and $4.2 \mathrm{~km}$. Source attribution with TRACE indicated that the layer originated from Central and Central-South Chile, where wildfires occurred at the same time. The second case shows thin (geometrically and optically) aerosol layers, as observed by Polly ${ }^{X T}$, at altitudes of 5.5-7, 9, and $11 \mathrm{~km}$ after a long-range transport event from Australia. The retrieved optical properties, indicate that the layers consist of smoke particles. The retrieved optical parameters for the two case studies are summarized in Table 1.

\subsection{Lofted smoke layers from South America}

From 4 February to 5 February 2019, several lofted aerosol layers were observed between 1 and $4.5 \mathrm{~km}$ height. Figure 2 shows a two-day overview of main lidar parameters, the Sun-photometer-derived AOD, atmospheric thermodynamics, and a target classification measured by Polly ${ }^{X T}$. As indicated in Figure 2, a free-tropospheric aerosol plume with a geometrical thickness of $3 \mathrm{~km}$ was present on 4 February 2019 between 02:00 and 19:30 UTC. The target classification (Baars et al. (2017), Fig. 2d) clearly identifies this aerosol up to about $4.3 \mathrm{~km}$ height but was not able to identify the type of the aerosol particles present as a result of weak backscattering signals. The AOD during that day was low, with a mean value of 0.05 at the wavelength of 500 nm. From the beginning of the campaign until March 2019, the mean daily averaged aerosol optical thickness at Punta Arenas was found to be 0.03 (at $500 \mathrm{~nm}$ ), thus a slightly increased AOD was observed. The aforementioned layer is characterized by low depolarization ratio values that indicate the presence of spherical particles. From the Ångström exponent (Figure 2a), we can conclude that the layer consisted mainly of fine-mode aerosol particles (i.e. particles smaller than $1 \mu \mathrm{m}$ ).

The following day, on 5 February 2019, a descending layer was observed between 07:00 and 12:00 UTC. The layer extents from 1 to $4.2 \mathrm{~km}$ height. In contrast to the layer from the previous day, this one is characterized by higher backscatter and low to moderate depolarization ratio with the most pronounced features found between 1.6 and $2.8 \mathrm{~km}$. The higher values of volume linear depolarization ratio, with respect to the previous day, indicate the presence of non-spherical particles. Similarly to the previous day, the AOD during that event was low, with a maximum and a mean value of 0.09 and 0.05 respectively (at $500 \mathrm{~nm}$ ), which is however still three times higher than the average. Around 18:00 UTC we observe the formation of a cloud, which according to the target classification consists of ice crystals, thus indicating that ice formation is most likely supported by the advection of the smoke particles acting as INP, as discussed below.

Further context of the air masses arriving at Punta Arenas is given by the HYSPLIT backward trajectory analysis shown in Figs. 3 and 4. The 10-day backward trajectories presented in Fig. 3 show that the vast majority of the air parcels arriving over Punta Arenas at $3000 \mathrm{~m}$ height originated from the southern Pacific Ocean. Shortly (1-2 days) before the arrival of the air parcels to Punta Arenas, they passed over the regions of Central and Central-South Chile (Figs. 3, 4a). Fig. 3c demonstrates that no precipitation occurred while the trajectories passed over the land masses. Air masses crossed above lands that were categorized as forest, savanna, grass and barren (Fig. 4b) and belong to South America (Fig. 4a). According to FIRMS (Fire Information for Resource Management System), on the 2nd and 3rd of February 2019, when the air parcels were located 
above the aforementioned regions, active fires and wildfires occurred over the region passed by the trajectories (not shown here). During the summer months (December to February), wildfires are common in Chile, especially between the regions of Valparaíso and Los Lagos, due to the extremely dry conditions and the prevailing westerlies. Relative humidity in the aerosol layer (Fig. 3b, Fig. 2e,f) was mostly below $60 \%$ and therefore we do not expect any hygroscopicity effects on the aerosol observed. As the air masses crossed above active fire regions 1-2 days before they were observed by our system, the presence of partly coated soot particles is expected. Apart from smoke particles, soil dust is also expected to be present in the observed layer due to turbulent fire-related winds that developed above the burning areas (Nisantzi et al., 2014; Wagner et al., 2018).

The backscatter coefficient (Fig. 5a) shows a similar behaviour for all three wavelengths with mean values of $0.90 \pm 0.25$ $\mathrm{Mm}^{-1} \mathrm{sr}^{-1}, 0.67 \pm 0.23 \mathrm{Mm}^{-1} \mathrm{sr}^{-1}$ and $0.34 \pm 0.11 \mathrm{Mm}^{-1} \mathrm{sr}^{-1}$ for 355, 532 and $1064 \mathrm{~nm}$ respectively. The maximum values for all wavelengths are observed around $1.5 \mathrm{~km}$. Backscatter-related Ångström exponents of $0.76 \pm 0.23$ and $0.97 \pm$ 0.29 at the wavelength pairs of $355 / 532 \mathrm{~nm}$ and 532/1064 nm, respectively were determined by lidar observations (Fig. 5c), and indicate the presence of coarse particles within the smoke layer. The extinction coefficient (not shown here) reached values up to $65 \mathrm{Mm}^{-1}$ at $355 \mathrm{~nm}$ and $39 \mathrm{Mm}^{-1}$ at $532 \mathrm{~nm}$ within the smoke layer. These values are typical for smoke layers and within the range of values previously reported in the literature (Amiridis et al., 2009; Kanitz et al., 2014; Haarig et al., 2018). Given the depolarization ratio values (Fig. 5d and discussion below), the coarse particles are dust particles (Tesche et al., 2009a; Ansmann et al., 2009). In comparison, Foth et al. (2019) reported a backscatter-related Ångström exponent (532/1064 $\mathrm{nm}$ ) of $0.56 \pm 0.21$ for a Patagonian dust layer and of $0.61 \pm 0.1$ for a smoke plume originating from Australia. Below $2.4 \mathrm{~km}$ the spectral dependency of the light absorbing smoke particles is evident. Above that altitude, backscatter-related Ångström exponents are roughly the same at both wavelength pairs. Mean lidar ratio (Fig. 5b) values were $49 \pm 12 \mathrm{sr}$ and $24 \pm 18 \mathrm{sr}$ for 355 and $532 \mathrm{~nm}$, respectively. The lidar ratios reported here are in consistency with previously published results (Balis et al., 2003; Müller et al., 2005; Tesche et al., 2009b; Giannakaki et al., 2010; Tesche et al., 2011; Baars et al., 2012; Kanitz et al., 2013; Baars et al., 2016). However, it should be noted that differences in the burned vegetation type, location (e.g. Eastern Europe, Siberia, Canada), fire type (smoldering or flaming combustion) and the age of the smoke particles are inducing the relatively large range of values reported in the literature. Within the smoke plume, linear particle depolarization ratio (Fig. 5d) ranges from $2 \%$ to $14 \%$ (mean: $7.6 \pm 3.6 \%$ ) at $532 \mathrm{~nm}$ with a maximum being observed between 2.2 and $2.3 \mathrm{~km}$. The slightly elevated particle linear depolarization ratio at this altitude can be explained by the presence of irregularly shaped soil dust particles (Nisantzi et al., 2014) along with some partly coated soot particles. The smoke-dust mixture is mostly confined between 2.0 and $2.8 \mathrm{~km}$ and it was well identified by the target classification algorithm as a partly non-spherical mixture (Fig. 2d).

The potential impact of this event on cloud and precipitation evolution and life cycle can be investigated by means of CCN and INP concentrations. CCN and INP number concentrations have been derived for this plume (1- $4.2 \mathrm{~km})$, uncertainty range for this approach is of a factor of 2 and 3, respectively (Mamouri and Ansmann, 2016). The lidar-derived total CCN concentration, given for $0.2 \%$ supersaturation with respect to liquid water, has a layer mean value and a standard deviation of $642 \pm 192 \mathrm{~cm}^{-3}$. The contribution of dust to the total $\mathrm{CCN}$ concentration is about $6 \%$ and the rest is attributed to soot particles. The obtained CCN number concentration is found to be strongly increased compared to other values reported for this 
region. Hamilton et al. (2014) reported much lower monthly mean values of CCN concentration for January (50 to $100 \mathrm{~cm}^{-3}$ ).

For comparison, Schmale et al. (2018) reported mean CCN concentrations within the range of 1200 to $1500 \mathrm{~cm}^{-3}$ (at $0.2 \%$ water supersaturation) for central Europe. We can therefore conclude that the $\mathrm{CCN}$ concentration was significantly increased due to the advection of smoke/dust, but was still below the levels typically observed in Central Europe. The parameterizations used for the derivation of the INP number concentration (Ullrich et al., 2017) correspond to soot particles in the immersion freezing temperature regime (see Fig. 2f). From the lidar observations, a layer mean of $284 \pm 166$ INP per L (at $-20{ }^{\circ} \mathrm{C}$ ) was derived. This value corresponds only to soot particles since the contribution of dust particles to the total INP number concentration at the chosen temperature is weak and almost negligible. The INP number concentration is found to be elevated for the Southern Hemisphere, especially when compared with the typical values of the region (annual 1-5 $\times 10^{-3}$ INP/L for an activation temperature of $-15{ }^{\circ} \mathrm{C}$ ), where marine aerosol is the dominant aerosol type of INPs (Vergara-Temprado et al., 2017).

\subsection{Long-range transported smoke layers from Australia}

The next event of lofted aerosol layers that occurred during the DACAPO-PESO campaign was observed about one month after the previous layers (sect. 3.1), on 11 March 2019. The temporal evolution of the event, by means of basic lidar parameters, aerosol target classification, AOD, and thermodynamic profiles, is depicted in Figure 6. The AOD during that day was low, with a daily mean of $0.03(500 \mathrm{~nm})$. The layers were observed between 02:00 and 13:00 UTC and between 5 and $12 \mathrm{~km}$ altitude. In contrast with the observations from 5 February 2019, where the layer was located between 1 and $4.2 \mathrm{~km}$ height, these layers were geometrically thin (approx. $1 \mathrm{~km}$ ), and are located at considerably higher altitudes (see Fig. 6b, 6d) but stacked upon each other. The backscatter coefficient values vary within the three layers, with the maximum being observed for the highest layer, which was observed at around 11-12 km height (Fig. 6b). The highest layer can be separated from the other layers in terms of depolarization ratio as it is the only one that consists of particles causing depolarization (Fig. 6c). Due to the low particle concentration and the uncertainties induced by the high altitude of the layers (decreasing signal-to-noise ratio with height), the target classification algorithm could not assign a specific aerosol type to the particles observed within the layer (Fig. 6d). Apart from these high altitude layers, we also observed clouds, mostly confined in the lowest $2 \mathrm{~km}$. Thus in this specific case, we have no evidence that the aerosol did influence cloud formation, but nevertheless the particles may have the potential to do so if atmospheric conditions change.

This observed stratification of the multiple aerosol layers is a characteristic feature of plumes advected over transcontinental scales (Müller et al., 2005). The long-range transport can be confirmed based on the back-trajectory analyses that are presented in Figs. 7 and 8. As indicated by the 10-day HYSPLIT backward trajectories (Figs. 7, 8a), all the air parcels arriving at Punta Arenas on 11 March 2019, at 06:00 UTC and at $11 \mathrm{~km}$ altitude, originate from the southwestern coast of Australia and travelled at high altitudes above $10 \mathrm{~km}$ (Fig. 7a). Before crossing the South Pacific Ocean, the air masses (above $5.5 \mathrm{~km}$ ) appear to have a significant residence time above lands characterized as savanna/shrub and slightly less time above regions of grass, crops and forests (Fig. 8b). According to FIRMS, when the air masses where above the southern parts of Australia, Tasmania and New Zealand (approx. 9 days before they were observed above Punta Arenas), there was a high count of active fires (not shown here) in all the aforementioned regions. Similarly to the previous case, there are no hygroscopicity effects on the particles within 
the observed layers, since the relative humidity (Fig. 7b) of the air masses observed above Punta Arena was less than $25 \%$. In addition, there was no washout of the carried particles via wet deposition since the modeled total precipitation was almost negligible (less than $1 \mathrm{~mm}$, Fig. 7c).

The height profiles of the backscatter coefficient, Ångström exponents and particle linear depolarization ratio as derived from the lidar measurements of 11 March 2019, between 2:45 and 3:40 UTC for the three lofted layers are shown in Fig. 9. Profiles of extinction coefficient and lidar ratio are not presented due to low signal to noise ratio at the altitudes of interest.

The three different layers are characterized by pronounced backscatter coefficients (Fig. 9a). More specifically, the backscatter coefficient reached values up to 0.15 and $0.08 \mathrm{Mm}^{-1} \mathrm{sr}^{-1}$ for the layer located between 5.5 and $7 \mathrm{~km}, 0.09$ and 0.06 $\mathrm{Mm}^{-1} \mathrm{sr}^{-1}$ for the middle layer located around $9 \mathrm{~km}$, and 0.35 and $0.18 \mathrm{Mm}^{-1} \mathrm{sr}^{-1}$ for the highest smoke layer observed around the altitude of $11 \mathrm{~km}$ (at 532 and $1064 \mathrm{~nm}$ respectively). The backscatter-related Ångström exponent (Fig. 9b) at the wavelength pair of 532/1064 $\mathrm{nm}$ has a similar behavior for the lowest and highest layers with values up to 0.8 , suggesting wavelength dependency and indicating the absence of coarse-mode aerosol particles. For the layer located at the altitude of 9 $\mathrm{km}$, the Ångström exponent is considerably lower, with a mean of $0.22 \pm 0.07$, suggesting the presence of larger particles.

The particle linear depolarization ratio (Fig. 9c) is height-independent up to $10 \mathrm{~km}$ with values of less than $2 \%$. Similar values of particle linear depolarization ratio (<3\%) have been reported by Baars et al. (2011) for aged smoke in the Amazon rain forest during the dry season. Values of that range indicate that most of the particles observed are spherical in shape (i.e. smoke particles). More specifically, for the middle layer with the very low Ångström exponent values, we can conclude that most likely it consists of rather large, spherical particles of continental aerosol. Above $10 \mathrm{~km}$ height, we observe a sharp increase of the particle depolarization ratio, until it reaches its maximum (9.5\%) within the highest aerosol layer, at an altitude of $11 \mathrm{~km}$. Mean depolarization ratio values within this layer were $8.3 \pm 1.02 \%$ at $532 \mathrm{~nm}$. This increase of the depolarization ratio reveals that within the highest and driest $(\mathrm{RH}<10 \%)$ layer there were irregularly shaped, partly coated soot particles. Dry, depolarizing smoke layers in the upper troposphere/lower stratosphere have been observed previously. Burton et al. (2012) observed over Mexico City, a similar smoke layer at a height of $8 \mathrm{~km}$ with a depolarization ratio of $9 \%$ at $532 \mathrm{~nm}$. The increased depolarization ratio for dry smoke layers in the stratosphere was observed by Haarig et al. (2018) and compared to more humid smoke layers in the lower troposphere with low values for the depolarization ratio $(<5 \%)$. For an extensive literature overview on aged and fresh smoke properties based on multiwavelength lidar observations, readers may refer to Haarig et al. (2018).

INP number concentration was derived for the upper layer, which was observed around the altitude of $11 \mathrm{~km}$. Since the temperature in the layer is below $-35^{\circ} \mathrm{C}$ (Fig. 6e), the deposition nucleation freezing parameterization for soot of Ullrich et al. (2017) is used. The whole backscatter coefficient was attributed to smoke particles, as the separation of dust and smoke does not work for smoke layers in the upper troposphere and lower stratosphere with their enhanced depolarization ratios. For an assumed supersaturation with respect to ice of $20 \%$, an INP number concentration of $1.07 \times 10^{3} \pm 714.9 \mathrm{~L}^{-1}$ was derived for ambient temperature. For the same superaturation and an assumed fixed temperature of $-55^{\circ} \mathrm{C}$, the INP number concentration would be higher $1.96 \times 10^{3} \pm 759.5 \mathrm{~L}^{-1}$. Immersion freezing and $\mathrm{CCN}$ activation are not important at that temperature range. Based on satellite observations, a supersaturation with respect to ice of $15-20 \%$ is found to be the best choice in cirrus clouds in 
the northern midlattitudes (Lamquin et al., 2012). The high numbers of smoke INP observed at $11 \mathrm{~km}$ height will impact cirrus formation as soon as cooling or lifting of the air mass leads to an increase of relative humidity. Homogeneous ice formation will be suppressed, as it requires supersaturations of around $40 \%$ with respect to ice (KÄrcher and Jensen, 2017), while sufficient INP are present to form ice at much lower humidities.

\section{Long-term analysis of occurrence of lofted layers}

Similarly to the ALPACA campaign (Kanitz et al., 2013; Foth et al., 2019), lofted layers were observed more frequently than expected in the pristine environment of Punta Arenas in 2019. Figure 10 gives an overview of the occurrence of lofted layers observed by the lidar in Punta Arenas during the DACAPO-PESO campaign until the end of 2019. In total, lofted layers were observed on 16 different days (3.9\%). Most of the layers were both optically and geometrically thin. According to AERONET, the averaged daily mean AOD of the days, on which lofted aerosol layers occurred, was as low as 0.05 at $500 \mathrm{~nm}$ wavelength. In addition, almost all layers were non-depolarizing, indicating that they consisted mainly of spherical particles. The only exceptions were the layer presented in Sec. 3.1, and a thin layer that was observed on 3 December 2019 (slighlty depolarizing). Nevertheless, such layers have the potential to influence cloud formation in this environment which is supposed to be almost pristine. Even small perturbations could therefore influence cloud properties strongly, while in the polluted northern hemisphere such perturbations would not be observable. This notion is also corroborated by the study of Villanueva et al. (2020), who discuss the hemispheric differences in the effect of mineral dust on heterogeneous ice formation.

10-day HYSPLIT backward trajectories for all the layers were performed, and revealed that the main origins of the air masses were the southern Oceans including Australia and New Zealand. To be more specific, layers observed until October 2019 originated mainly from the Southern Pacific and the Southern Ocean (and consisted of marine particles mostly), with only a fraction tracing back to the southern tips of Australia and South America (e.g. Sec. 3.1). Their origin and optical properties (not presented here), indicate that they were likely mainly consisting of large and spherical particles. The layers observed in November and December 2019 were originating mainly from Australia. Given the origin of the air masses, their altitude and geometrical as well as optical properties, the layers can be directly linked to the outstanding Australian bushfires of 2019-20. For a more detailed overview of these Australian bushfires on stratopsheric aerosol conditions refer to Ohneiser et al. (2020).

\section{Conclusions and outlook}

During the first 14 months of the DACAPO-PESO campaign, significant lofted layers were observed regularly above Punta Arenas. Two events were studied and presented in detail, based on observations from the multiwavelength Raman lidar Polly $X T$. The Raman lidar observations in combination with the HYSPLIT backward trajectory analysis allowed the identification of the aerosol. In the first case, the lofted aerosol layers originated from Central and Central-South Chile and were identified as smoke layers, mixed with soil dust. Smoke and dust particles were probably mixed near the source and lofted to higher altitudes via 
convection. In the second case, several geometrically and optically thin smoke layers were observed, after long-range transport from Australia.

The differences in the obtained optical properties between the observed layers, reflect differences in the amount and the age (chemical composition) of the observed smoke particles. As it can been seen from Table 1, the 532-nm particle depolarization ratio for the smoke and soil dust mixtures is slightly lower than the one for the pure smoke layer. In the first case, the smoke particles within the layer were freshly emitted (emitted 1-2 days before observation), while in the second case, the smoke particles were aged (observed 9 days after emission). Previous studies have shown that the depolarization ratio values at 532 $\mathrm{nm}$ for smoke freshly emitted into the atmosphere are generally low (due to the sphericity of the newly formed particles) and even lower for aged smoke particles (Burton et al. (2012, 2015); Haarig et al. (2018)). The elevated depolarization values of the smoke layer of the first case can additionally be attributed to the presence of soil dust and the resulting elevated mixing ratio of smoke and dust particles (Sugimoto and Lee, 2006; Tesche et al., 2009a). In addition, differences in RH are one of the main reasons for the different depolarization ratios. The backscatter-related Ångström exponent at the wavelength pair of 532/1064 nm exhibit similar behavior for both layers, with slightly higher values for the aged pure smoke layer, indicating a predominance of fine mode particles.

In comparison to the prevailing marine conditions in the region of Punta Arenas, biomass burning sources acted as an effective source of CCN and INP. Smoke advection from Central and Central-South Chile affected significantly the available $\mathrm{CCN}$ and INP in the lower troposphere. Both CCN and INP number concentration were higher than usual for the first case and likely contributed to the characteristics of an ice cloud that was observed only a couple of hours later (cloud formation, Fig. 2d). In addition, smoke particles advected from Australia at high altitudes were found to likely facilitate the formation of ice crystals.

The Southern Oceans and more specifically Punta Arenas, are usually characterized as pristine environments, where clean marine aerosol conditions prevail. However, this study demonstrates that this is not always the case. Lofted aerosol layers, transported either from short or long distances, occur regularly and influence radiation and cloud formation processes above the region. Even small perturbations influence cloud properties strongly above Punta Arenas, while in the polluted northern hemisphere such perturbations would not be observable.

Data availability. The Polly ${ }^{X T}$ lidar data are available at TROPOS upon request (polly@ tropos.de). GDAS1 meteorological data are available and can be downloaded at the webpage of NOAA (https://ready.arl.noaa.gov/READYamet.php). AERONET sun-photometer data were downloaded from the AERONET web page (AERONET, 2019). Trajectories are calculated with the NOAA HYSPLIT model (HYSPLIT, 2019).

Author contributions. MR, PS, CJ, RE, BB and FZ are responsible for the instrumentation and collected the observational data. AAF, ZY and HB analyzed the lidar and AERONET data. MR analysed the HYSPLIT data and provided the corresponding figures. MH derived the INP 
https://doi.org/10.5194/acp-2020-453

Preprint. Discussion started: 25 May 2020

(C) Author(s) 2020. CC BY 4.0 License.

(c) (1)

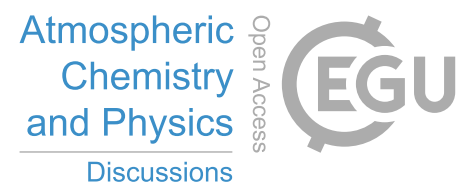

and $\mathrm{CCN}$ concentrations. UW has contributed in several discussions regarding the optical effects of smoke. AAF prepared the manuscript in 315 close cooperation with HB and AA.

Competing interests. The authors declare that they have no conflict of interest.

Acknowledgements. Parts of the research leading to these results have received funding from the European Union's Horizon 2020 research and innovation programme under grant agreement no. 654109 (ACTRIS). 


\section{References}

Althausen, D., Engelmann, R., Baars, H., Heese, B., Ansmann, A., Muller, D., and Komppula, M.: Portable Raman Lidar Polly(XT) for Automated Profiling of Aerosol Backscatter, Extinction, and Depolarization, Journal of Atmospheric and Oceanic Technology, 26, 23662378, https://doi.org/10.1175/2009jtecha1304.1, 2009.

Amiridis, V., Balis, D. S., Giannakaki, E., Stohl, A., Kazadzis, S., Koukouli, M. E., and Zanis, P.: Optical characteristics of biomass burning aerosols over Southeastern Europe determined from UV-Raman lidar measurements, Atmospheric Chemistry and Physics, 9, 2431-2440, https://doi.org/10.5194/acp-9-2431-2009, 2009.

Ansmann, A. and Müller, D.: Lidar and atmospheric aerosol particles, p. 105-141, Springer, New York, 2005.

Ansmann, A., Baars, H., Tesche, M., Muller, D., Althausen, D., Engelmann, R., Pauliquevis, T., and Artaxo, P.: Dust and smoke transport from Africa to South America: Lidar profiling over Cape Verde and the Amazon rainforest, Geophysical Research Letters, 36, 5, https://doi.org/10.1029/2009g1037923, 2009.

Baars, H., Ansmann, A., Althausen, D., Engelmann, R., Artaxo, P., Pauliquevis, T., and Souza, R.: Further evidence for significant smoke transport from Africa to Amazonia, Geophysical Research Letters, 38, 6, https://doi.org/10.1029/2011gl049200, <GotoISI>:/WOS: $000296157100002,2011$.

Baars, H., Ansmann, A., Althausen, D., Engelmann, R., Heese, B., Muller, D., Artaxo, P., Paixao, M., Pauliquevis, T., and Souza, R.: Aerosol profiling with lidar in the Amazon Basin during the wet and dry season, Journal of Geophysical Research-Atmospheres, 117, 16, https://doi.org/10.1029/2012jd018338, 2012.

Baars, H., Kanitz, T., Engelmann, R., Althausen, D., Heese, B., Komppula, M., Preissler, J., Tesche, M., Ansmann, A., Wandinger, U., Lim, J. H., Ahn, J. Y., Stachlewska, I. S., Amiridis, V., Marinou, E., Seifert, P., Hofer, J., Skupin, A., Schneider, F., Bohlmann, S., Foth, A., Bley, S., Pfuller, A., Giannakaki, E., Lihavainen, H., Viisanen, Y., Hooda, R. K., Pereira, S. N., Bortoli, D., Wagner, F., Mattis, I., Janicka, L., Markowicz, K. M., Achtert, P., Artaxo, P., Pauliquevis, T., Souza, R. A. F., Sharma, V. P., van Zyl, P. G., Beukes, J. P., Sun, J. Y., Rohwer, E. G., Deng, R. R., Mamouri, R. E., and Zamorano, F.: An overview of the first decade of Polly(NET): an emerging network of automated Raman-polarization lidars for continuous aerosol profiling, Atmospheric Chemistry and Physics, 16, 5111-5137, https://doi.org/10.5194/acp-16-5111-2016, <GotoISI>://WOS:000376937000022https://www.atmos-chem-phys.net/16/ 5111/2016/acp-16-5111-2016.pdf, 2016.

Baars, H., Seifert, P., Engelmann, R., and Wandinger, U.: Target categorization of aerosol and clouds by continuous multiwavelengthpolarization lidar measurements, Atmospheric Measurement Techniques, 10, 3175-3201, https://doi.org/10.5194/amt-10-3175-2017, 2017.

Balis, D. S., Amiridis, V., Zerefos, C., Gerasopoulos, E., Andreae, M., Zanis, P., Kazantzidis, A., Kazadzis, S., and Papayannis, A.: Raman lidar and sunphotometric measurements of aerosol optical properties over Thessaloniki, Greece during a biomass burning episode, Atmospheric Environment, 37, 4529-4538, https://doi.org/10.1016/s1352-2310(03)00581-8, 2003.

Belegante, L., Bravo-Aranda, J. A., Freudenthaler, V., Nicolae, D., Nemuc, A., Ene, D., Alados-Arboledas, L., Amodeo, A., Pappalardo, G., D’Amico, G., Amato, F., Engelmann, R., Baars, H., Wandinger, U., Papayannis, A., Kokkalis, P., and Pereira, S. N.: Experimental techniques for the calibration of lidar depolarization channels in EARLINET, Atmospheric Measurement Techniques, 11, 1119-1141, https://doi.org/10.5194/amt-11-1119-2018, <GotoISI>://WOS:000426082100001, 2018. 
Burton, S. P., Ferrare, R. A., Hostetler, C. A., Hair, J. W., Rogers, R. R., Obland, M. D., Butler, C. F., Cook, A. L., Harper, D. B., and Froyd, Measurement Techniques, 5, 73-98, https://doi.org/10.5194/amt-5-73-2012, <GotoISI>://WOS:000300233500004, 2012.

Burton, S. P., Hair, J. W., Kahnert, M., Ferrare, R. A., Hostetler, C. A., Cook, A. L., Harper, D. B., Berkoff, T. A., Seaman, S. T., Collins, J. E., Fenn, M. A., and Rogers, R. R.: Observations of the spectral dependence of linear particle depolarization ratio of aerosols using NASA Langley airborne High Spectral Resolution Lidar, Atmospheric Chemistry and Physics, 15, 13 453-13 473, https://doi.org/10.5194/acp15-13453-2015, <GotoISI>://WOS:000367189600011, 2015.

Bühl, J., Seifert, P., Wandinger, U., Baars, H., Kanitz, T., Schmidt, J., Myagkov, A., Engelmann, R., Skupin, A., Heese, B., Klepel, A., Althausen, D., and Ansmann, A.: LACROS: the Leipzig Aerosol and Cloud Remote Observations System, vol. 8890 of SPIE Remote Sensing, SPIE, https://doi.org/10.1117/12.2030911, 2013.

D’Amico, G., Amodeo, A., Baars, H., Binietoglou, I., Freudenthaler, V., Mattis, I., Wandinger, U., and Pappalardo, G.: EARLINET Single Calculus Chain - overview on methodology and strategy, Atmospheric Measurement Techniques, 8, 4891-4916, https://doi.org/10.5194/amt-8-4891-2015, <GotoISI>://WOS:000365978100021, 2015.

Engelmann, R., Kanitz, T., Baars, H., Heese, B., Althausen, D., Skupin, A., Wandinger, U., Komppula, M., Stachlewska, I. S., Amiridis, V., Marinou, E., Mattis, I., Linne, H., and Ansmann, A.: The automated multiwavelength Raman polarization and water-vapor lidar Polly(XT): the neXT generation, Atmospheric Measurement Techniques, 9, 1767-1784, https://doi.org/10.5194/amt-9-1767-2016, 2016.

Foth, A., Kanitz, T., Engelmann, R., Baars, H., Radenz, M., Seifert, P., Barja, B., Fromm, M., Kalesse, H., and Ansmann, A.: Vertical aerosol distribution in the southern hemispheric midlatitudes as observed with lidar in Punta Arenas, Chile (53.2 degrees S and 70.9 degrees W), during ALPACA, Atmospheric Chemistry and Physics, 19, 6217-6233, https://doi.org/10.5194/acp-19-6217-2019, 2019.

Freudenthaler, V.: About the effects of polarising optics on lidar signals and the Delta 90 calibration, Atmospheric Measurement Techniques, 9, 4181-4255, https://doi.org/10.5194/amt-9-4181-2016, 2016.

Friedl, M. A., McIver, D. K., Hodges, J. C. F., Zhang, X. Y., Muchoney, D., Strahler, A. H., Woodcock, C. E., Gopal, S., Schneider, A., Cooper, A., Baccini, A., Gao, F., and Schaaf, C.: Global land cover mapping from MODIS: algorithms and early results, Remote Sensing of Environment, 83, 287-302, https://doi.org/10.1016/s0034-4257(02)00078-0, <GotoISI>://WOS:000179160200019, 2002.

Giannakaki, E., Balis, D. S., Amiridis, V., and Zerefos, C.: Optical properties of different aerosol types: seven years of combined Raman-elastic backscatter lidar measurements in Thessaloniki, Greece, Atmospheric Measurement Techniques, 3, 569-578, https://doi.org/10.5194/amt-3-569-2010, 2010.

Haarig, M., Ansmann, A., Baars, H., Jimenez, C., Veselovskii, I., Engelmann, R., and Althausen, D.: Depolarization and lidar ratios at 355, 532, and $1064 \mathrm{~nm}$ and microphysical properties of aged tropospheric and stratospheric Canadian wildfire smoke, Atmospheric Chemistry and Physics, 18, 11 847-11 861, https://doi.org/10.5194/acp-18-11847-2018, 2018.

Hamilton, D. S., Lee, L. A., Pringle, K. J., Reddington, C. L., Spracklen, D. V., and Carslaw, K. S.: Occurrence of pristine aerosol environments on a polluted planet, Proceedings of the National Academy of Sciences of the United States of America, 111, 18 466-18 471, https://doi.org/10.1073/pnas.1415440111, 2014.

Holben, B. N., Eck, T. F., Slutsker, I., Tanre, D., Buis, J. P., Setzer, A., Vermote, E., Reagan, J. A., Kaufman, Y. J., Nakajima, T., Lavenu, F., Jankowiak, I., and Smirnov, A.: AERONET - A federated instrument network and data archive for aerosol characterization, Remote Sensing of Environment, 66, 1-16, https://doi.org/10.1016/s0034-4257(98)00031-5, 1998.

Holben, B. N., Tanre, D., Smirnov, A., Eck, T. F., Slutsker, I., Abuhassan, N., Newcomb, W. W., Schafer, J. S., Chatenet, B., Lavenu, F., Kaufman, Y. J., Castle, J. V., Setzer, A., Markham, B., Clark, D., Frouin, R., Halthore, R., Karneli, A., O’Neill, N. T., Pietras, C., Pinker, 
R. T., Voss, K., and Zibordi, G.: An emerging ground-based aerosol climatology: Aerosol optical depth from AERONET, Journal of Geophysical Research-Atmospheres, 106, 12 067-12 097, https://doi.org/10.1029/2001jd900014, <GotoISI>://WOS:000169300200027, 2001.

Immler, F. and Schrems, O.: LIDAR measurements of cirrus clouds in the northern and southern midlatitudes during INCA $\left(55^{\circ} \mathrm{N}, 53^{\circ} \mathrm{S}\right)$ : A comparative study, Geophysical Research Letters, 29, 56-1-56-4, https://doi.org/10.1029/2002gl015077, https://agupubs.onlinelibrary. wiley.com/doi/abs/10.1029/2002GL015077, 2002.

Kanitz, T., Seifert, P., Ansmann, A., Engelmann, R., Althausen, D., Casiccia, C., and Rohwer, E. G.: Contrasting the impact of aerosols at northern and southern midlatitudes on heterogeneous ice formation, Geophysical Research Letters, 38, 5, https://doi.org/10.1029/2011g1048532, 2011.

Kanitz, T., Ansmann, A., Engelmann, R., and Althausen, D.: North-south cross sections of the vertical aerosol distribution over the Atlantic Ocean from multiwavelength Raman/polarization lidar during Polarstern cruises, Journal of Geophysical Research-Atmospheres, 118, 2643-2655, https://doi.org/10.1002/jgrd.50273, 2013.

Kanitz, T., Ansmann, A., Foth, A., Seifert, P., Wandinger, U., Engelmann, R., Baars, H., Althausen, D., Casiccia, C., and Zamorano, F.: Surface matters: limitations of CALIPSO V3 aerosol typing in coastal regions, Atmospheric Measurement Techniques, 7, 2061-2072, https://doi.org/10.5194/amt-7-2061-2014, 2014.

KÄrcher, B. and Jensen, E. J.: Microscale characteristics of homogeneous freezing events in cirrus clouds, Geophysical Research Letters, 44, 2027-2034, https://doi.org/10.1002/2016gl072486, https://agupubs.onlinelibrary.wiley.com/doi/abs/10.1002/2016GL072486, 2017.

Lamquin, N., Stubenrauch, C. J., Gierens, K., Burkhardt, U., and Smit, H.: A global climatology of upper-tropospheric ice supersaturation occurrence inferred from the Atmospheric Infrared Sounder calibrated by MOZAIC, Atmos. Chem. Phys., 12, 381-405, https://doi.org/10.5194/acp-12-381-2012, https://www.atmos-chem-phys.net/12/381/2012/, 2012.

Mamouri, R. E. and Ansmann, A.: Potential of polarization lidar to provide profiles of CCN- and INP-relevant aerosol parameters, Atmospheric Chemistry and Physics, 16, 5905-5931, https://doi.org/10.5194/acp-16-5905-2016, <GotoISI>://WOS:000376938100025, 2016.

Mattis, I., D’Amico, G., Baars, H., Amodeo, A., Madonna, F., and Iarlori, M.: EARLINET Single Calculus Chain - technical - Part 2: Calculation of optical products, Atmospheric Measurement Techniques, 9, 3009-3029, https://doi.org/10.5194/amt-9-3009-2016, $<$ GotoISI >://WOS:000381094100004, 2016.

Müller, D., Mattis, I., Wandinger, U., Ansmann, A., Althausen, D., and Stohl, A.: Raman lidar observations of aged Siberian and Canadian forest fire smoke in the free troposphere over Germany in 2003: Microphysical particle characterization, Journal of Geophysical ResearchAtmospheres, 110, 16, https://doi.org/10.1029/2004jd005756, 2005.

Nisantzi, A., Mamouri, R. E., Ansmann, A., and Hadjimitsis, D.: Injection of mineral dust into the free troposphere during fire events observed with polarization lidar at Limassol, Cyprus, Atmospheric Chemistry and Physics, 14, 12 155-12 165, https://doi.org/10.5194/acp14-12155-2014, <GotoISI>://WOS:000345290700010, 2014.

Ohneiser, K., Ansmann, A., Baars, H., Seifert, P., Barja, B., Jimenez, C., Radenz, M., Teisseire, A., Floutsi, A., Haarig, M., Engelmann, R., Zamorano, F., Bühl, J., and Wandinger, U.: Smoke of extreme Australian bushfires observed in the stratosphere over Punta Arenas, Chile, in January 2020: optical thickness, lidar ratios, and depolarization ratios at 355 and $532 \mathrm{~nm}$, Atmos. Chem. Phys. Discuss., 2020, 1-16, https://doi.org/10.5194/acp-2020-96, https://www.atmos-chem-phys-discuss.net/acp-2020-96/, 2020.

Radenz, M. and Seifert, P.: Software for automated trajectory analysis: trace, https://doi.org/10.5281/zenodo.2576559, 2019. 
Ristori, P., Otero, L., Jin, Y., Barja, B., Shimizu, A., Barbero, A., Salvador, J., Bali, J. L., Herrera, M., Etala, P., Acquesta, A., Quel, E., Sugimoto, N., and Mizuno, A.: Saver.net lidar network in southern South America, EPJ Web Conf., 176, 09 011, https://doi.org/10.1051/ epjconf/201817609011, 2018.

Schmale, J., Henning, S., Decesari, S., Henzing, B., Keskinen, H., Sellegri, K., Ovadnevaite, J., Pohlker, M. L., Brito, J., Bougiatioti, A., Kristensson, A., Kalivitis, N., Stavroulas, I., Carbone, S., Jefferson, A., Park, M., Schlag, P., Iwamoto, Y., Aalto, P., Aijala, M., Bukowiecki, N., Ehn, M., Frank, G., Frohlich, R., Frumau, A., Herrmann, E., Herrmann, H., Holzinger, R., Kos, G., Kulmala, M., Mihalopoulos, N., Nenes, A., O’Dowd, C., Petaja, T., Picard, D., Pohlker, C., Poschl, U., Poulain, L., Prevot, A. S. H., Swietlicki, E., Andreae, M. O., Artaxo, P., Wiedensohler, A., Ogren, J., Matsuki, A., Yum, S. S., Stratmann, F., Baltensperger, U., and Gysel, M.: Long-term cloud condensation nuclei number concentration, particle number size distribution and chemical composition measurements at regionally representative observatories, Atmospheric Chemistry and Physics, 18, 2853-2881, https://doi.org/10.5194/acp-18-2853-2018, <GotoISI>://WOS:000426312200002, 2018.

Schneider, C., Glaser, M., Kilian, R., Santana, A., Butorovic, N., and Casassa, G.: Weather Observations Across the Southern Andes at 53 S, Physical Geography, 24, 119, https://doi.org/10.2747/0272-3646.24.2.97, 2003.

Stein, A. F., Draxler, R. R., Rolph, G. D., Stunder, B. J. B., Cohen, M. D., and Ngan, F.: NOAA'S HYSPLIT ATMOSPHERIC TRANSPORT AND DISPERSION MODELING SYSTEM, Bulletin of the American Meteorological Society, 96, 2059-2077, https://doi.org/10.1175/bams-d-14-00110.1, 2015.

Sugimoto, N. and Lee, C. H.: Characteristics of dust aerosols inferred from lidar depolarization measurements at two wavelengths, Applied Optics, 45, 7468-7474, https://doi.org/10.1364/ao.45.007468, <GotoISI>://WOS:000240886000032, 2006.

Tesche, M., Ansmann, A., Muller, D., Althausen, D., Mattis, I., Heese, B., Freudenthaler, V., Wiegner, M., Esselborn, M., Pisani, G., and Knippertz, P.: Vertical profiling of Saharan dust with Raman lidars and airborne HSRL in southern Morocco during SAMUM, Tellus Series B-Chemical and Physical Meteorology, 61, 144-164, https://doi.org/10.1111/j.1600-0889.2008.00390.x, 2009a.

Tesche, M., Ansmann, A., Muller, D., Althausen, D., Engelmann, R., Freudenthaler, V., and Gross, S.: Vertically resolved separation of dust and smoke over Cape Verde using multiwavelength Raman and polarization lidars during Saharan Mineral Dust Experiment 2008, Journal of Geophysical Research-Atmospheres, 114, 14, https://doi.org/10.1029/2009jd011862, 2009b.

Tesche, M., Gross, S., Ansmann, A., Muller, D., Althausen, D., Freudenthaler, V., and Esselborn, M.: Profiling of Saharan dust and biomassburning smoke with multiwavelength polarization Raman lidar at Cape Verde, Tellus Series B-Chemical and Physical Meteorology, 63, 649-676, https://doi.org/10.1111/j.1600-0889.2011.00548.x, 2011.

Ullrich, R., Hoose, C., Mohler, O., Niemand, M., Wagner, R., Hohler, K., Hiranuma, N., Saathoff, H., and Leisner, T.: A New Ice Nucleation Active Site Parameterization for Desert Dust and Soot, Journal of the Atmospheric Sciences, 74, 699-717, https://doi.org/10.1175/jas-d16-0074.1, <GotoISI>://WOS:000394344800004, 2017.

Vergara-Temprado, J., Murray, B. J., Wilson, T. W., O’Sullivan, D., Browse, J., Pringle, K. J., Ardon-Dryer, K., Bertram, A. K., Burrows, S. M., Ceburnis, D., DeMott, P. J., Mason, R. H., O’Dowd, C. D., Rinaldi, M., and Carslaw, K. S.: Contribution of feldspar and marine organic aerosols to global ice nucleating particle concentrations, Atmospheric Chemistry and Physics, 17, 3637-3658, https://doi.org/10.5194/acp-17-3637-2017, <GotoISI>://WOS:000397928200002, 2017.

Villanueva, D., Heinold, B., Seifert, P., Deneke, H., Radenz, M., and Tegen, I.: The day-to-day co-variability between mineral dust and cloud glaciation: a proxy for heterogeneous freezing, Atmos. Chem. Phys., 20, 2177-2199, https://doi.org/10.5194/acp-20-2177-2020, https://www.atmos-chem-phys.net/20/2177/2020/, 2020. 
https://doi.org/10.5194/acp-2020-453

Preprint. Discussion started: 25 May 2020

(c) Author(s) 2020. CC BY 4.0 License.

(c) (1)

465 Wagner, R., Jahn, M., and Schepanski, K.: Wildfires as a source of airborne mineral dust - revisiting a conceptual model using large-eddy simulation (LES), Atmospheric Chemistry and Physics, 18, 11 863-11 884, https://doi.org/10.5194/acp-18-11863-2018, 2018.

Wandinger, U., Freudenthaler, V., Baars, H., Amodeo, A., Engelmann, R., Mattis, I., Gross, S., Pappalardo, G., Giunta, A., D’Amico, G., Chaikovsky, A., Osipenko, F., Slesar, A., Nicolae, D., Belegante, L., Talianu, C., Serikov, I., Linne, H., Jansen, F., Apituley, A., Wilson, K. M., de Graaf, M., Trickl, T., Giehl, H., Adam, M., Comeron, A., Munoz-Porcar, C., Rocadenbosch, F., Sicard, M., Tomas, S., Lange, D., Kumar, D., Pujadas, M., Molero, F., Fernandez, A. J., Alados-Arboledas, L., Bravo-Aranda, J. A., Navas-Guzman, F., Guerrero-Rascado, J. L., Granados-Munoz, M. J., Preissler, J., Wagner, F., Gausa, M., Grigorov, I., Stoyanov, D., Iarlori, M., Rizi, V., Spinelli, N., Boselli, A., Wang, X., Lo Feudo, T., Perrone, M. R., De Tomasi, F., and Burlizzi, P.: EARLINET instrument intercomparison campaigns: overview on strategy and results, Atmospheric Measurement Techniques, 9, 1001-1023, https://doi.org/10.5194/amt-9-1001-2016, <GotoISI>://WOS: $000375613600010,2016$. 
https://doi.org/10.5194/acp-2020-453

Preprint. Discussion started: 25 May 2020

(c) Author(s) 2020. CC BY 4.0 License.

Atmospheric

Chemistry

(c) (i)

and Physics

Discussions

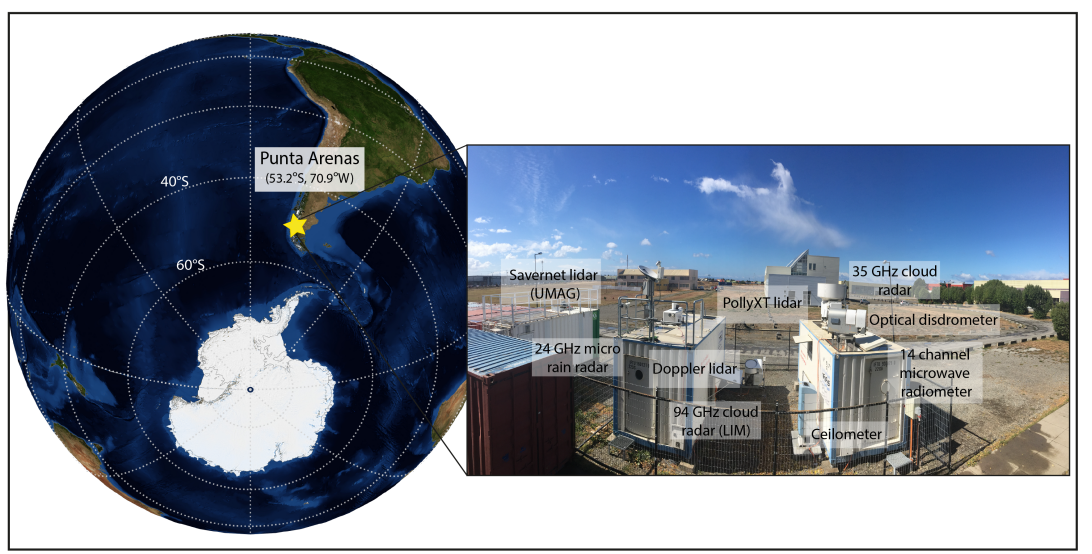

Figure 1. Map of the location of Punta Arenas (indicated by a yellow star) in Chile, South America. The LACROS observational facility, as deployed at UMAG, can be seen on the right side. 


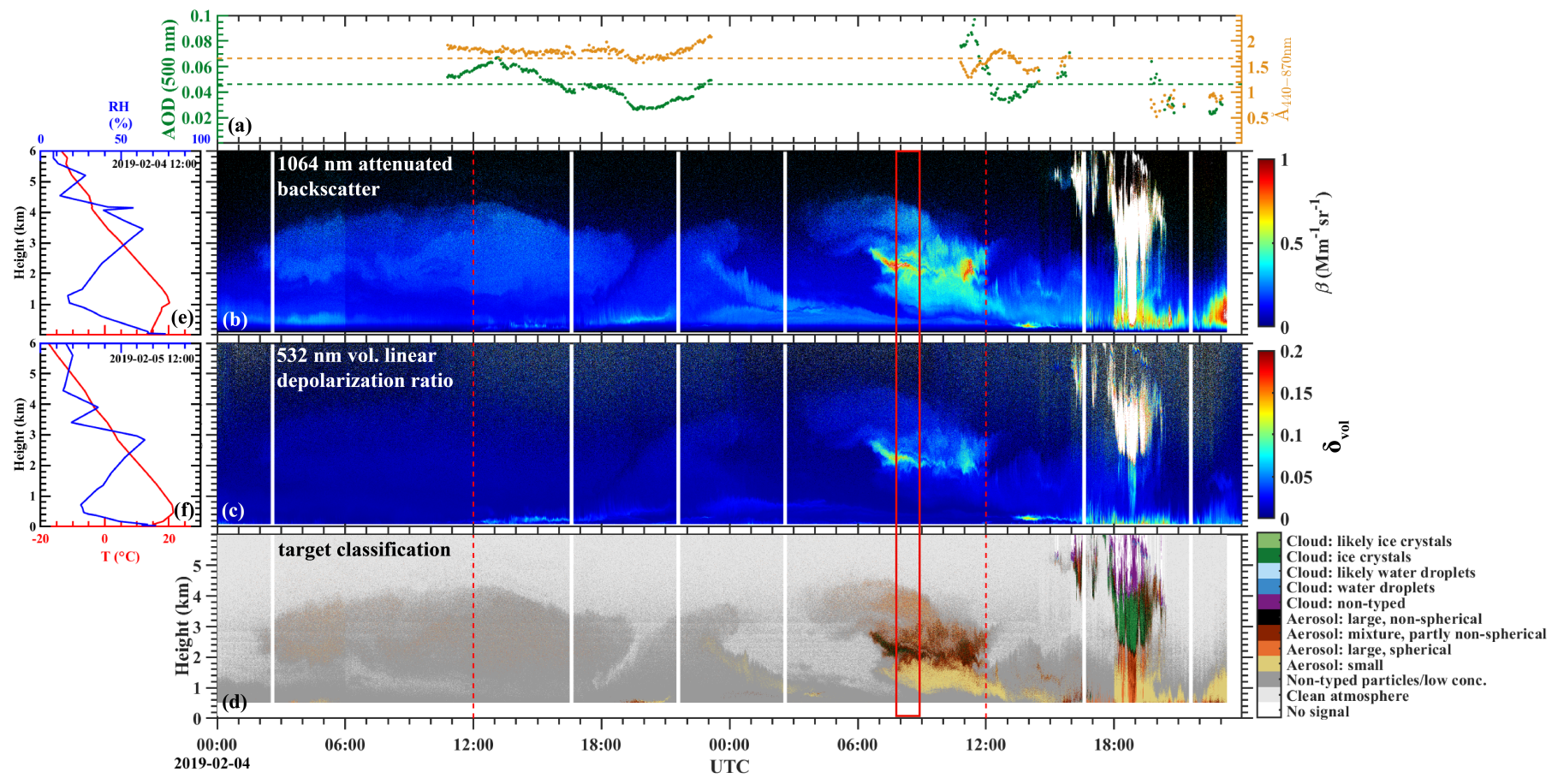

Figure 2. From the upper to the lower panel: (a) AOD at $500 \mathrm{~nm}$ and Ångström exponent for 440/870 nm (dashed lines indicate the mean), (b) attenuated backscatter coefficient at $1064 \mathrm{~nm}\left(\mathrm{Mm}^{-1} \mathrm{sr}^{-1}\right)$, (c) volume depolarization ratio (\% at $\left.532 \mathrm{mn}\right)$, and (d) target classification reflecting the atmospheric conditions over Punta Arenas from 4 February to 5 February 2019. Radiosonde launches are depicted with red dashed lines. The corresponding temperature and relative humidity profiles can be seen on the left panels (e, f). Vertical white lines indicate the automatic calibration of the linear depolarization ratio (Engelmann et al. (2016)). The averaging period for the profiles shown in Fig. 5 is indicated by the red rectangular. 
https://doi.org/10.5194/acp-2020-453

Preprint. Discussion started: 25 May 2020

(c) Author(s) 2020. CC BY 4.0 License.

(c) (i)

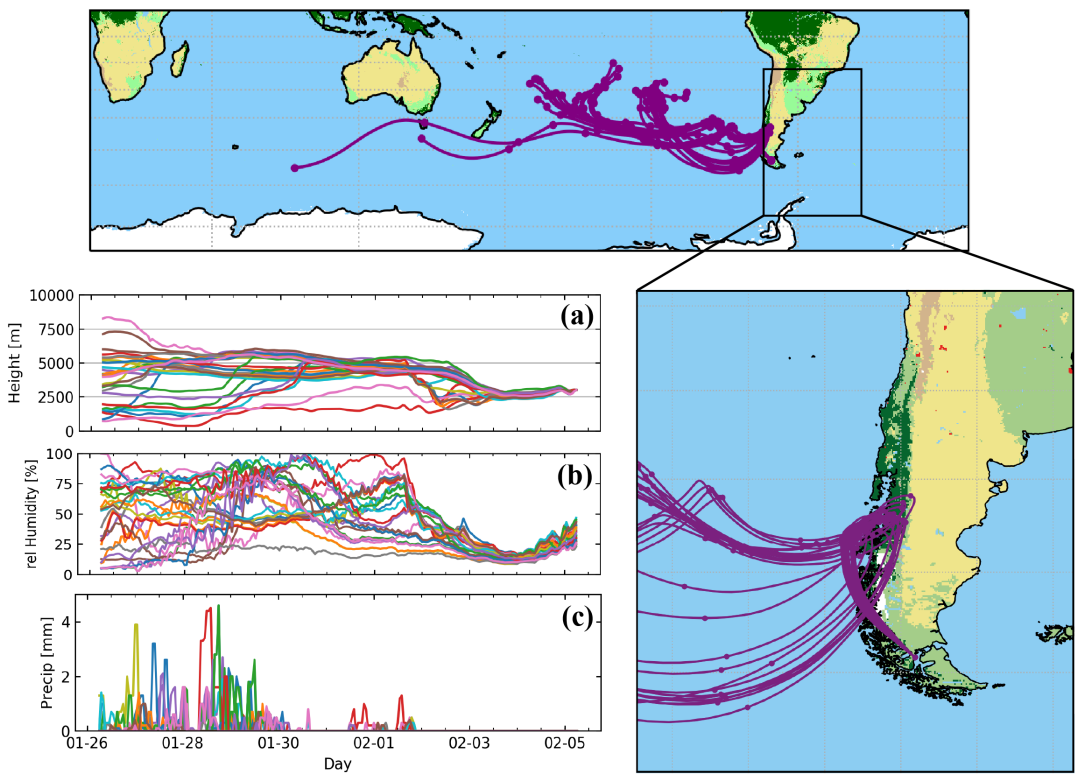

Figure 3. Top: the 10-day HYSPLIT backward trajectories (http://www.arl.noaa.gov/ready/hysplit4.html) ending at Punta Arenas, Chile, on 05 February 2019, 06:00 UTC, at $3 \mathrm{~km}$ altitude. Panels below show (a) the altitude (m) at which the air masses were traveling, (b) the relative humidity $(\%)$ of the air masses and (c) the precipitation in $\mathrm{mm}$. Right: Zoom of top panel. 


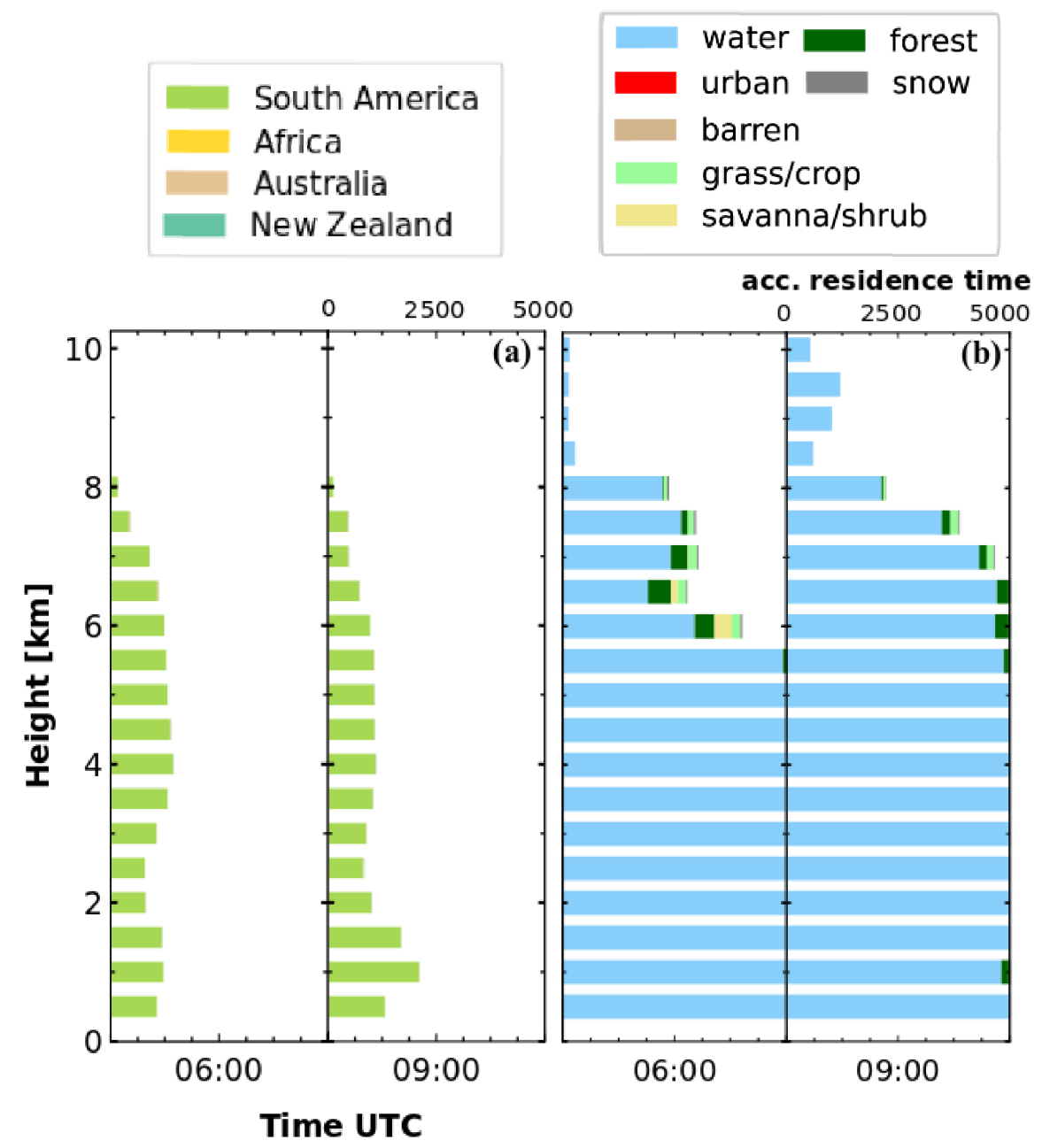

Figure 4. Accumulated residence time (h) of the air masses arriving at several heights over Punta Arenas on 05 February 2019. Above (a) geographical regions and (b) type of surface. 

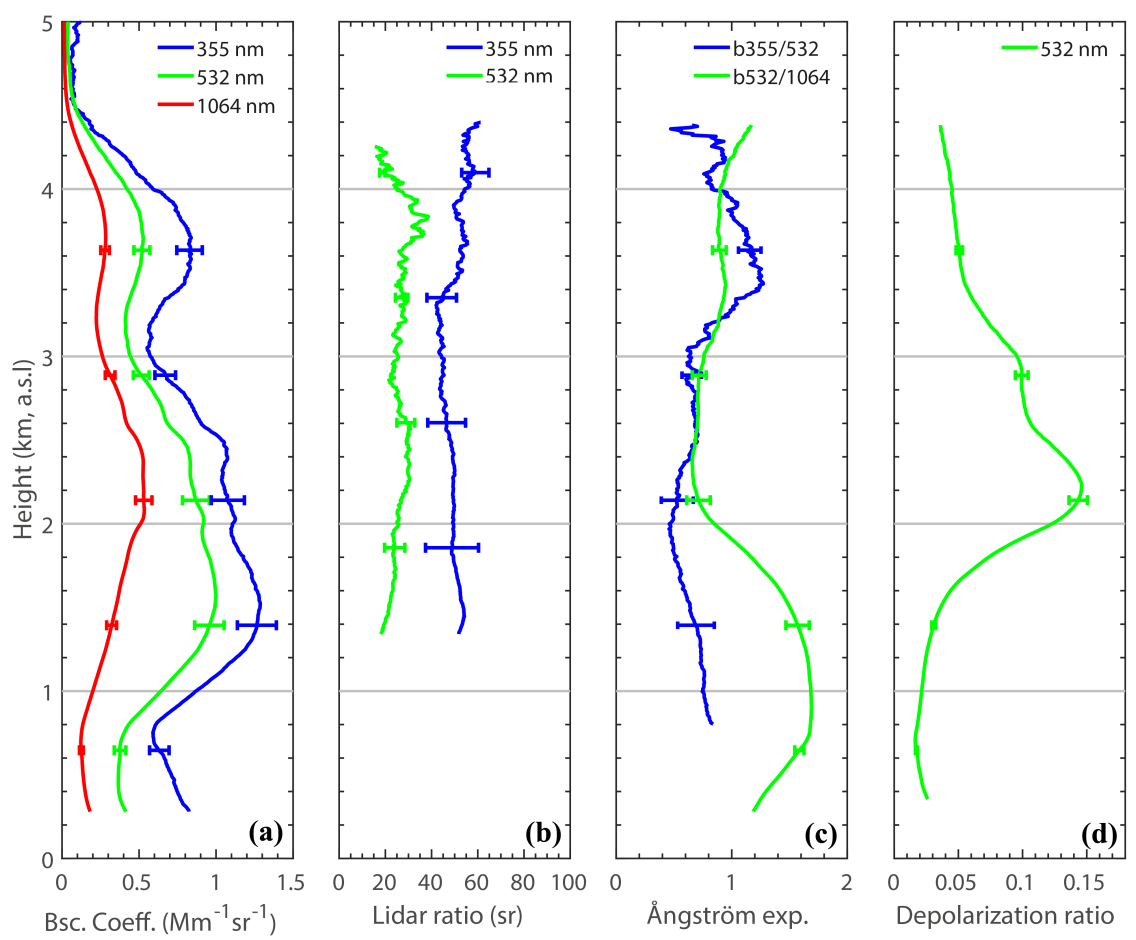

Figure 5. (a) Particle backscatter coefficients (at three wavelengths), (b) the extinction-to-backscatter ratios, (c) the corresponding backscatter-related Ångström exponents, and (d) particle linear depolarization ratio measured at Punta Arenas on 05 February 2019, 07:5108:57 UTC. 
https://doi.org/10.5194/acp-2020-453

Preprint. Discussion started: 25 May 2020

(C) Author(s) 2020. CC BY 4.0 License.
Atmospheric

Chemistry and Physics

Discussions

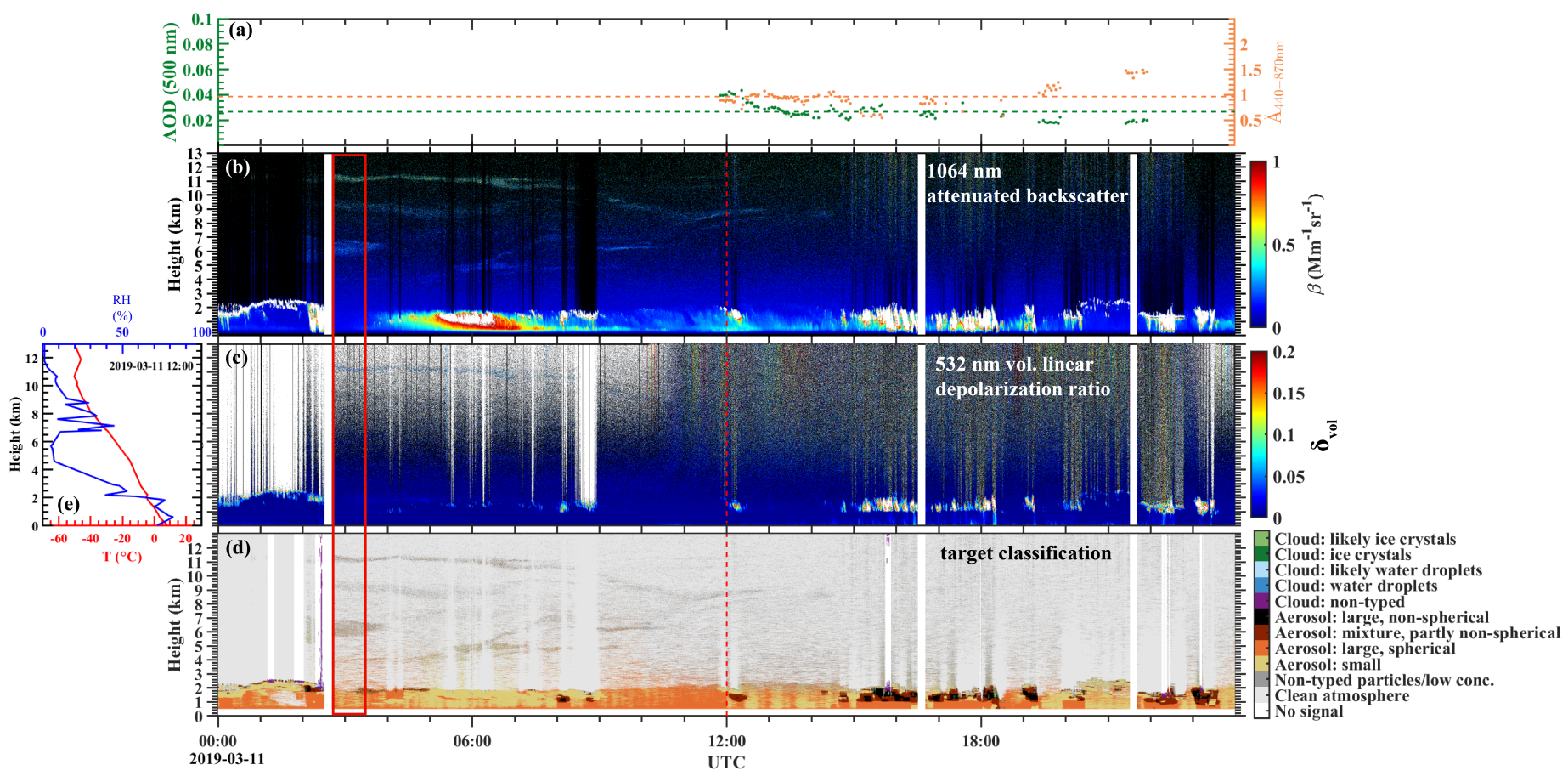

Figure 6. Same as Fig. 1 but for 11 March 2019. The averaging period for the profiles shown in Fig. 9 is indicated by the red rectangular. 
https://doi.org/10.5194/acp-2020-453

Preprint. Discussion started: 25 May 2020

(c) Author(s) 2020. CC BY 4.0 License.

Atmospheric

Chemistry

(c) (i)

and Physics

Discussions

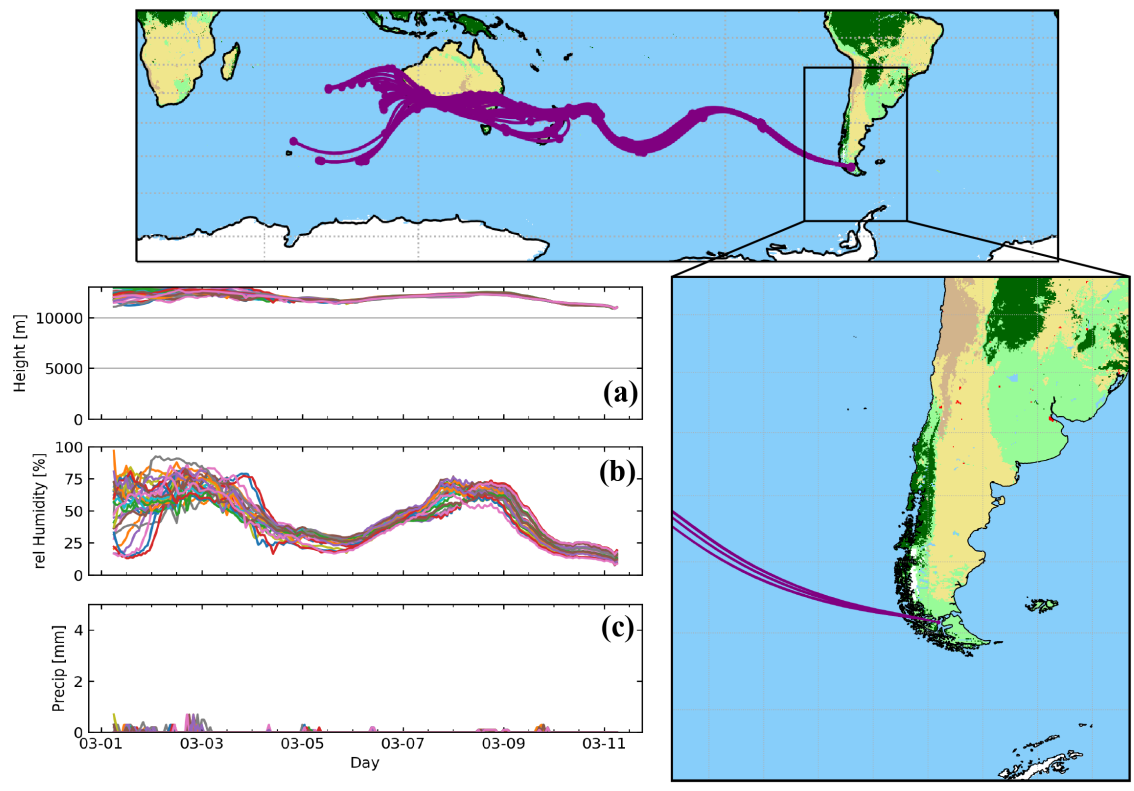

Figure 7. Same as Fig. 2 but for 11 March 2019, 06:00 UTC, at $11 \mathrm{~km}$ altitude. 


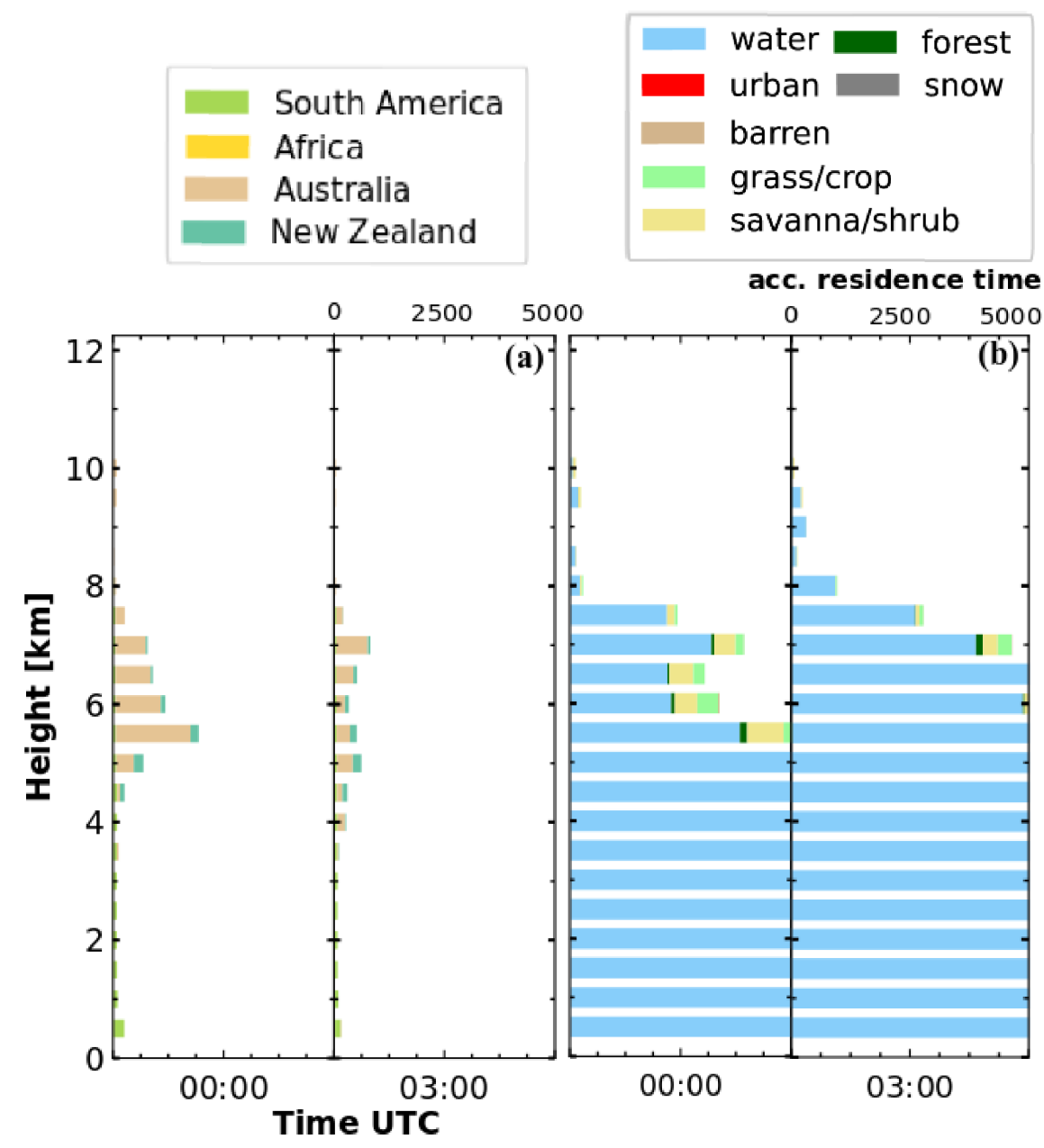

Figure 8. Same as Fig. 3 but for 11 March 2019. 

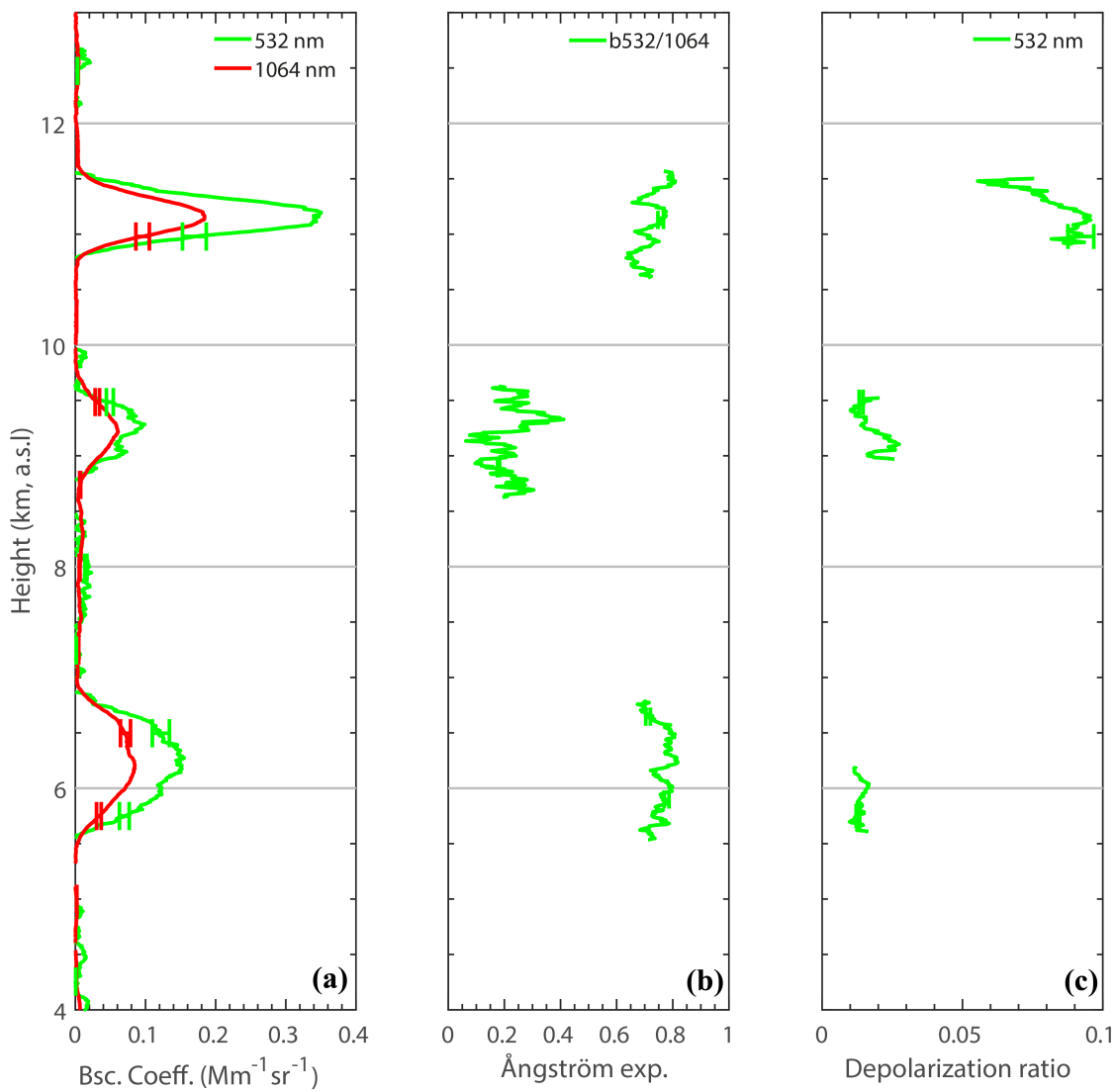

Figure 9. Mean profiles of (a) particle backscatter coefficients (at 532 and 1064 nm), (b) the corresponding backscatter-related Ångström exponent (for 532/1064 nm), and (c) particle linear depolarization ratio at $532 \mathrm{~nm}$ measured at Punta Arenas on 11 March 2019, 02:45- 03:40 UTC. 
https://doi.org/10.5194/acp-2020-453

Preprint. Discussion started: 25 May 2020

(C) Author(s) 2020. CC BY 4.0 License.

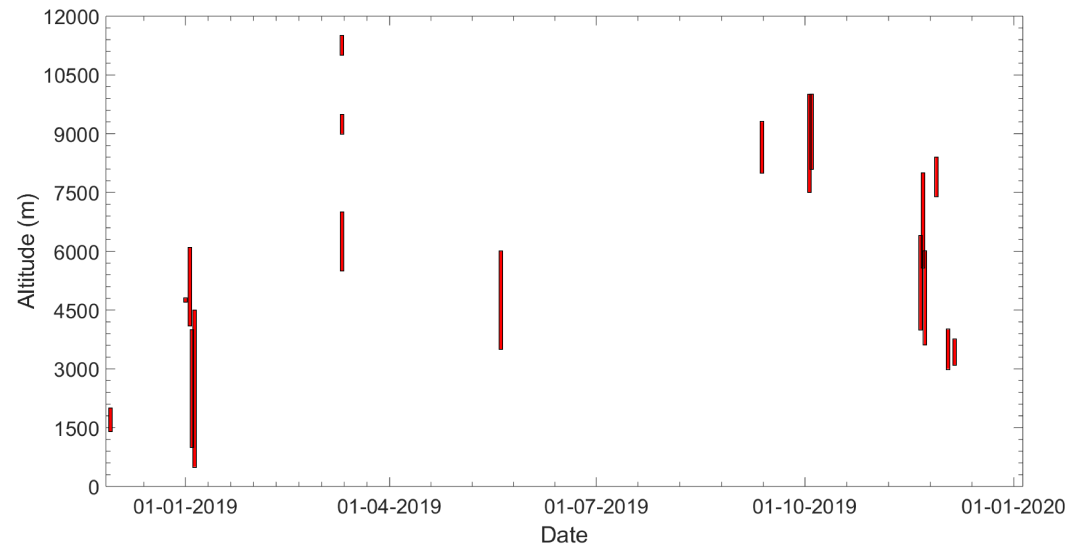

Figure 10. Occurrence and height boundaries of lofted aerosol layers in Punta Arenas between 29 Nov. and 31 Dec. 2019. 
https://doi.org/10.5194/acp-2020-453

Preprint. Discussion started: 25 May 2020

(c) Author(s) 2020. CC BY 4.0 License.

Table 1. Overview of aerosol optical properties as derived from Polly ${ }^{X T}$ LACROS in Punta Arenas on 05 February 2019 and 11 March 2019 (values correspond to the layer located at $11 \mathrm{~km}$ ). $\beta$ is the backscatter coefficient, $\mathrm{S}$ the lidar ratio, $\delta$ the particle linear depolarization ratio and $\AA$ the backscatter-related Ångström exponent. The subscript indicates the corresponding wavelength. All values correspond to averaged (mean) values per examined layer along with the standard deviation.

\begin{tabular}{ccccc}
\hline Date & $\beta_{355}, \beta_{532}, \beta_{1064}$ & $S_{355}, S_{532}$ & $\delta_{532}$ & $\AA_{355 / 532}, \AA_{532 / 1064}$ \\
$\left(M m^{-1} s r^{-1}\right)$ & $(s r)$ & $(\%)$ & \\
\hline 5 February 2019 & $0.90 \pm 0.25$ & $49 \pm 12$ & $7.6 \pm 0.23$ & $0.76 \pm 0.23$ \\
& $0.67 \pm 0.23$ & $24 \pm 18$ & & $0.97 \pm 0.29$ \\
& $0.34 \pm 0.11$ & & & \\
\hline \multirow{2}{*}{ 11 March 2019 } & - & - & $8.3 \pm 1.0$ & - \\
& $0.20 \pm 0.11$ & - & & $0.72 \pm 0.04$ \\
& $0.10 \pm 0.05$ & & & \\
\hline
\end{tabular}

